\title{
Examining Faculty Perception of Their Readiness to Teach Online
}

\author{
Florence Martin, Kiran Budhrani, and Chuang Wang \\ University of North Carolina Charlotte
}

\begin{abstract}
Faculty readiness to teach online is a state of faculty preparedness for online teaching. In this study, it is measured by faculty attitudes about the importance of online teaching competencies and faculty's perceptions of their ability to confidently teach online. Validity and reliability of faculty responses to an online instrument and factors related to faculty perception are examined. Descriptive statistics and item-level means for the competencies are provided. For course design, course communication, and technical competencies, faculty rated the perception of importance higher than they rated their ability in these areas, whereas for time management their perception of their ability was higher than their attitude about its importance. MANOVA showed significant differences in gender, years of teaching online, and delivery method for faculty perceptions of importance of online teaching competencies. Significant differences were also noted in years of teaching online and delivery method with respect to ability to teach online.
\end{abstract}

Keywords: faculty readiness, online teaching, faculty attitude, faculty ability, faculty perception

Martin, F., Budhrani, K., \& Wang, C. (2019). Examining faculty perception of their readiness to teach online. Online Learning, 23(3), 97-119. doi:10.24059/olj.v23i3.1555

\section{Examining Faculty Perception of Their Readiness to Teach Online}

Technological developments require faculty members to consider new ways to prepare, organize, deliver, and assess courses and learning materials for online teaching (Pagliari, Batts, \& McFadden, 2009; Sorcinelli \& Austin, 2006). Bawane and Spector (2009) argue that the competencies required to teach online are not substantially different from those needed to teach face-to-face; it is assumed that a faculty member's past teaching experience serves as foundation to teaching online (Wray, Lowenthal, Bates, \& Stevens, 2008). However, some researchers disagree with this idea and explain that teaching in the online modality is different from teaching in the classroom and that the online faculty member's role is different from that of a faculty member teaching in the classroom (Ko \& Rossen, 2017; Wray et al., 2008). Online faculty focus on instructional time and space, virtual management techniques, and the ability to engage students through virtual communication (Easton, 2003). 


\section{Online Teaching Competencies}

A competency is "a knowledge, skill or ability that enables one to effectively perform the activities of a given occupation or function to the standards expected in employment" (Richey, Fields, \& Foxon, 2001, p. 26). Online researchers have examined competencies in online technologies (Guasch, Alvarez, \& Espasa, 2010). Early work of Berge (1995) looked at conditions of successful online teaching and categorized four areas of competency: (1) pedagogical, (2) social, (3) managerial, and (4) technical. Subsequent researchers (Aydin, 2005; Bawane, \& Spector, 2009; Goodyear, Salmon, Spector, Steeples, \& Tickner, 2001; Guasch et al., 2010; Varvel, 2007; Williams, 2003) expanded Berge's (1995) work to describe faculty functions, roles, and competencies. Williams (2003) defines four general categories to describe faculty competencies in higher education: (1) learning and instruction, (2) communication and interaction, (3) management and administration, and (4) technology. Guasch et al. (2010) analyzed previous research on university teacher competencies for teaching and learning in virtual environments and concluded that online faculty take on a designing/planning function, social function, instructive function, technological domain, and management domain.

In this study, we examine four areas of online teaching competencies: course design, course communication, time management, and technical. We focused on these four competencies based on our review of literature and existing readiness instruments. This is described in detail in the Instrument subsection under the Methods section.

Course design. Course design is identified as a pedagogical competency, alongside course implementation, facilitation, and assessment (Varvel, 2007). The course design process involves planning instruction with course objectives, instructional strategies, activities, and assessments that align to objectives (Varvel, 2007). Major considerations when designing courses are defining appropriate activities and workload for students (Napier, Dekhane, \& Smith, 2011). Courses need to be organized into a structure, a course syllabus, and course guidelines to define requirements (Darabi, Sikorski, \& Harvey, 2006; Fein \& Logan, 2003; Ko \& Rossen, 2017; Palloff \& Pratt, 1999). Chunking information into modules enhances student learning (Fein \& Logan, 2003).

Effective strategies for online courses include discussions (De Gagne, 2009) and case studies. Case studies provide real-life examples to maintain student interest, motivation, and active learning (Gudea, 2005; Ryan, Carlton, \& Ali, 2004; Turner, 2005). Varvel (2007) explains that faculty need to evaluate the instructional effectiveness and value of learning materials for a course, as well as ensure those selected align to the given context, curriculum, and outcomes. Faculty also adjust materials based on credibility, clarity, validity, reliability, accuracy, currency, accessibility, usability, and quality of course resources (Varvel, 2007). Materials may include text; audio, video, and other delivery media; and simulations to aid student understanding, interpretation, and internalization of new information (Varvel, 2007).

Faculty must decide whether assessments should be redesigned for the online course (Fein \& Logan, 2003). Faculty need to design assessments considering whether students will work individually or interact with peers in groups, striking a balance between independent, interactive, and interdependent activities (Gunawardena, 1992). Courses also need to provide students with grading criteria (Ko \& Rossen, 2017). Course design involves not only preparing materials, course lectures, activities, and assessments in advance, but also providing clear expectations of assignments and/or activities and anticipating student questions (Darabi et al., 2006). Faculty must create an organized course where objectives, structure, content, activities, assessments, materials, and interaction components of the course are made explicit. 
Course communication. Goodyear et al. (2001) highlight the importance of interpersonal communication and interaction between the teacher and students in online courses. Faculty must be able to communicate through writing and/or audio to the students within the given learning modality (Varvel, 2007). Feedback needs to be adequate, timely, and prompt. Communication on rules and regulations, due dates, netiquette, course expectations, ethical practices, the code of conduct, and policies for the course as well as information about accessibility, privacy, and copyright are necessary (Coppola, Hiltz, \& Rotter, 2002; Darabi et al., 2006; Ko \& Rossen, 2001; Varvel, 2007).

Facilitating discussions is a key competency when teaching online (Redmond, 2011). Discussion forums, emails, and chats give educators a variety of tools to promote learnerinstructor, learner-content, and learner-learner interaction (Moore, 1993). Faculty must be able to moderate, participate in, and advance discussions to encourage participation (Darabi et al., 2006). Faculty should apply a variety of active, engaging, and effective communication methods, carry internal dialogue, and formulate effective responses (Varvel, 2007).

Time management. Competent faculty have adequate time-management skills so that lifestyle commitments do not interfere with the ability to instruct the course (Varvel, 2007). Online course design and planning is time-consuming and takes significantly longer for a first-timer, as all the course objectives, content, activities, and assessments have to be redesigned for an online format. The second time the online course is taught is less time-consuming compared to the first time (Visser, 2000).

Darabi et al. (2006) found that top-five tasks faculty spend most of their time on are assessing learners' attainment of learning objectives, providing feedback, injecting questions that promote higher order thinking, and providing directions for assignments. Faculty spend additional time outside of class to help struggling students, including addressing questions about students' technical difficulties (Napier et al., 2011). Faculty also spend time outside of class giving attention to details of student performance as they monitor students and maintain proper records and gradebooks (Coppola et al., 2002; Darabi et al., 2006; Varvel, 2007). Visser's (2000) comparative analysis revealed that the time and effort involved in course development and delivery may partially depend on the accumulation of faculty experience, level of institutional support, and technical support. Faculty experience on previous online course design and facilitation, and established support at the university might reduce the time for subsequent course design and facilitation. Aydin (2005) found that participants who were faculty and graduate assistants believed that the ability to manage time efficiently was very important for successful online teaching.

Technical. Technical competencies are specific to the use of the technology, independent of pedagogy (Varvel, 2007). They include technical knowledge (e.g., knowledge about how to use software, synchronous and asynchronous tools, operating systems, learning systems and tools, and Web browsers, and how to implement security updates) and proficiency in the use of current technology, the ability to troubleshoot technology issues, and the ability to assist learners effectively (Darabi et al., 2006; Varvel, 2007). The expansion of online content, Web 2.0 tools, and audio- and video-based learning materials has put pressure on faculty to curate digital online resources for online students (Espiritu, 2016). Faculty also need to learn how to select, manage, use, and/or produce videos for course lectures, welcome videos, and demonstrations. Designing a course that supplements or replaces classroom lectures with online content requires more technical competencies, such as instructional websites and interactive learning environments (Young, 1997). Faculty often get frustrated with technical glitches and the amount of time required to type text for 
instruction or communication (Coppola et al., 2002). Faculty must learn to access technical assistance, not only to seek help for their issues but also to ensure learners are provided assistance when required, especially students using adaptive/assistive technologies (Varvel, 2007). Faculty are increasingly expected to handle Web-based enrollment courses, as online gradebooks are becoming a norm (Brooks, 2010).

In our review of the literature, we found that the discourse among researchers on the competency frameworks, roles, requirements, and tasks to teach online is rich. There is, however, limited research on the readiness of faculty to perform these online teaching competencies. More importantly, such competencies differ for faculty by culture, contexts, organizations, and countries (Aydin, 2005; Bawane \& Spector, 2009; Guasch et al., 2010; Williams, 2003), which in turn implies that readiness will vary by these same factors. Thus, there is a need to further study faculty readiness to teach online.

\section{Faculty Readiness to Teach Online}

Several institutions use a readiness instrument to assess faculty readiness to teach online, but most of these are not systematically studied or empirically tested. Few researchers have studied faculty readiness for online teaching. Gay (2016) examined the assessment of online instructor elearning readiness before, during, and after course delivery. They found that the availability of online help desk services is an urgent need of online faculty. Lichoro (2015) found that faculty members do not feel adequately prepared to teach online. However, there is still a need to identify competencies to prepare faculty to teach online, and by doing so we will be providing guidance to prepare faculty to teach online. Downing and Dyment (2013) examined teacher educators' readiness and preparation for as well as their perceptions of preparing preservice teachers in a fully online environment and found that teachers considered online teaching time-consuming. Based on the research examined, it was found that faculty new to online teaching felt a lack of readiness to teach online and needed technical and pedagogical support, and time-management strategies.

We define faculty readiness to teach online as a state of faculty preparation for online teaching. Within the context of this study, we focus on two aspects of readiness: (1) faculty attitude on the importance of online teaching and (2) faculty perceptions of their ability to confidently teach online. Attitude refers to the viewpoint a person has about something and its personal relevance to them (Krosnick \& Petty, 1995). Ability has reference to the capacity to successfully perform (Ferguson, 1954). Since measuring faculty's direct ability was not possible, we focused on their perception of their ability to teach online. Several researchers have examined the relationships between attitude, ability, and readiness (Bayram \& Comek, 2009; Logan \& Johnston, 2009; Rollnick, Mason, \& Butler, 1999). However, researchers have not yet examined the relationships between attitude, ability, and online teaching readiness. 


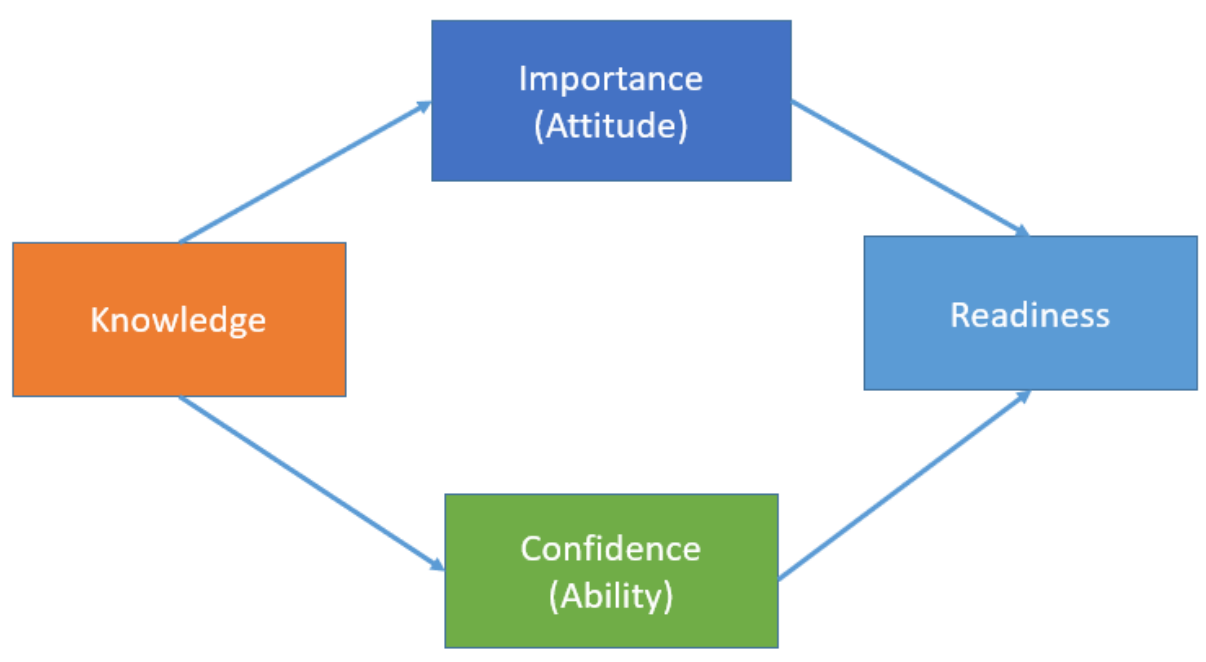

Figure 1. Theoretical framework for faculty readiness to teach online. Adapted from Health Behavior Change e-Book, by S. Rollnick, P. Mason, and C. C. Butler, 2010: Elsevier Health Sciences.

Attitude (importance). Since teaching in the online modality is different from teaching in the classroom, faculty competencies to teach online require faculty to adjust their attitudes towards technology and teaching. It is essential to examine faculty attitudes on the importance of the various competencies for online teaching. Students are likely to experience more positive learning outcomes when their faculty have positive attitudes towards online course delivery (Volery, 2000). Denis, Watland, Pirotte, and Verday (2004) emphasize that faculty rate competencies that promote student interaction and build student-instructor relationships as most important. In Denis et al.'s (2004) study, respondents rated pedagogical roles as most important. Darabi et al.'s (2006) study showed that faculty place most importance on managerial aspects of teaching, such as keeping records and maintaining course accuracy; the top-five tasks their respondents rated as important included reviewing the course for accuracy, assessing learners' attainment of learning objectives, and maintaining expertise in their subject area.

Ability (confidence). Instructor ability is conceptualized as the teachers' beliefs about or perceptions of their own competence at teaching, related to use of instructional strategies and teaching effectiveness (Lee \& Tsai, 2010). Research on online teaching ability can contribute to understanding how teachers' ability affects what they do when they teach online (Wallace, 2004) and contribute to the development of resources to best meet faculty development needs (Northcote, Gosselin, \& Reynaud, 2015). Northcote et al. (2015) measured online teaching ability, surveying the variations in self-confidence to carry out online teaching tasks, such as selecting technological resources, conducting virtual interaction, facilitating content migration, ensuring course alignment, and establishing course structure. Their study revealed that faculty had lowest selfefficacy in selecting technological resources and highest self-efficacy in online course alignment, which was to effectively align learning objectives, course assignments, assessment strategies, and learning activities within online courses. Aydin (2005) studied perceptions of ability and importance for online teaching competencies related to technology use, communication, time management, online education, and content. Results show that faculty have higher perceptions of the importance of these competencies and yet lower perceptions of their ability with regard to these competencies, recognizing that they need improvement to perform better at online teaching. 
Perception of online teaching ability was seen to improve with professional development programs for faculty (Northcote et al., 2015).

\section{Demographic Factors in Online Teaching}

Studies have examined gender differences in online teaching. Aydin's (2005) study found that gender had no effect on faculty's perception of roles and competencies. However, Briggs's (2005) survey found gender-specific differences in perceptions of the importance of the 11 online teaching roles and competencies. Chase (2002) found differences in gender on instructional design practice, particularly on course design. Shea (2007) found differences in gender pertaining to motivations to teach online. In other studies, men rated their ability to use instructional technology higher than women did, but both genders had similar frequencies of technology use (Spotts, Bowman, \& Mertz, 1997). Women faculty tended to explore more relational approaches to teaching and use technology for different purposes than men did (Campbell \& Varnhagen, 2002). Thus, gender differences related to teaching with technology are worth further investigation.

Other factors that influence faculty's positive attitudes toward teaching online are prior experience teaching online, availability of online courseware, improved training and facilities, feedback from students, and flexibility of time and teaching schedules (Clay, 1999). Shea's (2007) study showed that the number of times faculty had taught online was an important consideration in how motivated faculty are in the online modality; with more experience in the online modality, self-confidence levels increase. Less experienced faculty report that they struggle to communicate because of the absence of face-to-face interaction, are unfamiliar with effective online pedagogy, lack the opportunity to observe online teaching before engaging in it, lack the opportunity to experiment with the technologies of online teaching, and have inadequate time to learn about online teaching (Shea, 2007). Carrol, Sanmamed, and Sellés (2013) found that faculty who have more teaching experience online also have greater perceived ability to perform pedagogical competencies online.

\section{Purpose of This Study and Research Questions}

While several universities have a readiness measure to assess faculty's readiness to teach online, few studies have been systematically conducted to measure faculty readiness. The purpose of this study is to examine faculty perceptions on their readiness to teach online by examining their attitude about the importance of competencies and their perception of their ability to teach online. Research questions of this study include the following:

- What are faculty attitudes on the importance of online teaching competencies and faculty's perception of their ability to confidently to teach online?

- What demographic factors are related to faculty attitudes about online teaching competencies and their ability to teach online?

\section{Methods}

\section{Research Design}

This is a survey-based research study in which the SurveyShare electronic tool was utilized. Surveys are commonly used to elicit information about attitudes that are otherwise difficult to measure using observational techniques. Sometimes educators conduct descriptive research to obtain information to learn more about people's attitudes, opinions, demographics (e.g., gender, 
age), beliefs, and behaviors. Using a survey or the survey method as a means to collect data about people is common in descriptive research (Johnson \& Christen, 2004).

\section{Data Sources}

The survey was distributed through the SurveyShare electronic survey tool to three distribution lists in the United States: the Association for Educational Technology (AECT) Communications (1,984 members), the American Educational Research Association (AERA) Online Teaching and Learning Special Interest Group (250 members), and a southeastern public university's faculty (529 members) in the United States. We had a sentence in the recruitment email stating that this survey was to be completed by faculty who have taught online. A total of 205 faculty responded to the survey, of whom 144 (70\%) were female and $56(27 \%)$ were male. Five of the respondents $(3 \%)$ did not identify their gender. The mean age of the participants was 49.55 years, with a standard deviation of 10.94 years. Respondents from the AECT and AERA listserv and from the southeastern public university's faculty were not statistically significantly different from each other with respect to age, $t(188)=1.04, p=.30$; years of teaching, $\chi^{2}(d f=3)$ $=4.11, p=.34$; years of teaching online, $\chi^{2}(d f=3)=7.09, p=.07$, and gender, $\chi^{2}(d f=1)=2.17$, $p=.34$. As a result, all respondents were grouped together for further analyses. Table 1 presents a description of the participants, including age, gender, rank, delivery method, level, years teaching, and years teaching online.

Table 1

Faculty Demographic Characteristics

\begin{tabular}{|c|c|c|c|}
\hline \multirow{6}{*}{ Rank } & ariables & Frequency & \multirow{20}{*}{$\begin{array}{l}\text { Note. Not all participants responded to } \\
\text { all questions; thus, percentages are } \\
\text { based on the number who actually } \\
\text { responded to a particular question. }\end{array}$} \\
\hline & Full professor & $22(12.4 \%)$ & \\
\hline & Associate professor & $49(27.7 \%)$ & \\
\hline & Assistant professor & $43(24.3 \%)$ & \\
\hline & Instructor/lecturer & $54(30.5 \%)$ & \\
\hline & Clinical faculty & $9(5.1 \%)$ & \\
\hline \multirow{4}{*}{$\begin{array}{l}\text { Delivery } \\
\text { method }\end{array}$} & Asynchronous & $84(42.2 \%)$ & \\
\hline & Synchronous & $15(7.5 \%)$ & \\
\hline & Hybrid & $39(19.6 \%)$ & \\
\hline & Face-to-face & $61(30.7 \%)$ & \\
\hline \multirow[t]{2}{*}{ Level } & Undergraduate & $57(28.1 \%)$ & \\
\hline & Graduate & $146(71.9 \%)$ & \\
\hline \multirow[t]{4}{*}{ Years teaching } & $0-5$ years & $21(10.5 \%)$ & \\
\hline & $6-10$ years & $38(19.1 \%)$ & \\
\hline & $11-15$ years & $36(18.1 \%)$ & \\
\hline & More than 15 & $104(52.3 \%)$ & \\
\hline \multirow{4}{*}{$\begin{array}{l}\text { Years teaching } \\
\text { online }\end{array}$} & $0-5$ years & $94(46.3 \%)$ & \\
\hline & $6-10$ years & $54(26.6 \%)$ & \\
\hline & $11-15$ years & $35(17.2 \%)$ & \\
\hline & More than 15 & $20(9.9 \%)$ & \\
\hline
\end{tabular}




\section{Instrument}

The Faculty Readiness to Teach Online (FRTO) instrument (Table 2) was developed by the authors with reference to the literature (theoretical models and previous research). Research studies (Downing \& Dyment, 2013; Gay, 2010; Lichoro, 2015) were reviewed to identify a framework and instrument that can be used to measure faculty readiness to teach online.

We also reviewed the 20-item readiness instrument from the University of Toledo (2017), which had categorized the readiness skills into basic technical skills, learning management system (Blackboard) experience, course planning and time management, and communication. The faculty self-assessment used when preparing for online teaching at Pennsylvania State University was also reviewed. The 30-item survey ranked items within three categories: technical, administrative, and pedagogical competencies. For this research, we did not adopt either of the existing instruments because we did not feel that these instruments captured the entirety of faculty readiness in the lens we were looking through. We used the broader categories from the University of Toledo survey and included technical, design, time management, and communication in the design of the instrument. We chose to use some of the items from the Pennsylvania State University survey (Pennsylvania State University, 2017) but preferred the categorization from the University of Toledo survey (University of Toledo, 2017). Content validity was checked with three experts in instructional technology and three additional faculty who teach online. The survey initially had six categories and 28 items and was narrowed down to four categories, but the number of items increased to 32 from the process. Two of the sections-(1) engagement and (2) assessment and evaluation-were merged with other sections. Also, the items increased based on recommendations from content experts about items they felt were missing.

Based on our review of the literature (e.g., Downing \& Dyment, 2013; Gay, 2016; Lichoro, 2015) and our examination of faculty readiness instruments adopted by universities (University of Toledo and Pennsylvania State University), we designed a framework of faculty readiness to teach online including course design, course communication, time management, and technical competencies (see Figure 1).

In addition to demographic information, the instrument consists of two constructs: attitude based on importance and perception of ability. The same items were used for each construct, and the respondents were asked to rate how important each competence is for online teaching and how well they are able to accomplish the tasks based upon their own judgment of their competencies. The competencies fall into four categories: course design (nine items), course communication (10 items), time management (six items), and technical competence (seven items). In the section for attitude, respondents were asked to rate the importance of the competencies on a 5-point Likert scale from 1 (not important at all) to 5 (very important). In the section for ability, respondents were asked to rate their capability to accomplish the tasks based upon their own judgment of their competencies on a 5-point Likert scale from 1 (I cannot do it at all) to 5 (I can do it well). Cronbach's alpha for all items for attitude was 0.88 and for ability was 0.92 .

\section{Data Collection}

The survey was created using SurveyShare, which is an online survey tool. Institutional Review Board approval was received. Recruitment emails were sent to instructional technology listservs for the AECT and the AERA Online Teaching and Online SIG. Recruitment emails were also sent to the faculty who teach online at a southeastern university. 


\section{Data Analysis Procedure}

Confirmatory factor analysis was employed to examine the structural aspect of validity (Messick, 1995). The goodness-of-fit indices included standardized root mean square residual (SRMR), root mean square error of approximation (RMSEA), comparative fit index (CFI), incremental fit index (IFI), and the $90 \%$ confidence intervals of RMSEA. Some research studies have questioned the validity of Hu and Bentler's (1999) two-index strategy in model fit assessment (Fan \& Sivo, 2005), and suggested that this two-index strategy was based on very restrictive assumptions and tended to reject adequately fitting models (Marsh, Hau, \& Wen, 2004). Therefore, this study placed more emphasis on the combinations of multiple goodness-of-fit indices. The suggestions provided by LISREL to add paths from observable variables to latent variables were not followed because this could mechanically fit the model not suggested by theory (MacCallum, Roznowski, \& Necowitz, 1992). Only two pairs of items were allowed to covary because these items have a lot in common.

Descriptive statistics (means and standard deviations) are reported both at the item level, at the subscale level, and also by various demographic factors. Cronbach's alpha was used to check the internal consistencies of the responses to the survey items. Pearson correlation coefficients were calculated to show the relationship between the subscales. Multivariate analysis of variance (MANOVA) was employed to examine the differences among faculty in their responses to the survey with respect to gender, rank, teaching experience, teaching online experience, primary level of teaching, primary delivery method, support received, and required training. We used effect sizes from MANOVA ( small $=.01$; moderate $=.06$; large $=.14$ ) to document the size of obtained differences (Cohen, 1988).

\section{Survey Validation}

Cronbach's alpha was used to show the internal consistency (reliability) of the participants' responses to the FRTO survey. Cronbach's alpha for all items for attitude was 0.88 , and for ability was 0.92 . For faculty attitudes on importance, the subscales were 0.79 (course design), 0.82 (course communication), 0.82 (time management), and 0.81 (technical). For their perception of ability, the subscales were 0.92 (course design), 0.86 (course communication), 0.83 (time management), and 0.88 (technical).

The confirmatory factor analyses showed a fairly good fit of the data to the model: $\mathrm{CFI}=$ $.92, \mathrm{IFI}=.92, \mathrm{SRMR}=.089, \mathrm{RMSEA}=.093$, and $90 \%$ confidence interval of RMSEA ranged from .090 to .096 . The two-level structure of the CFA is shown in Figure 2. 


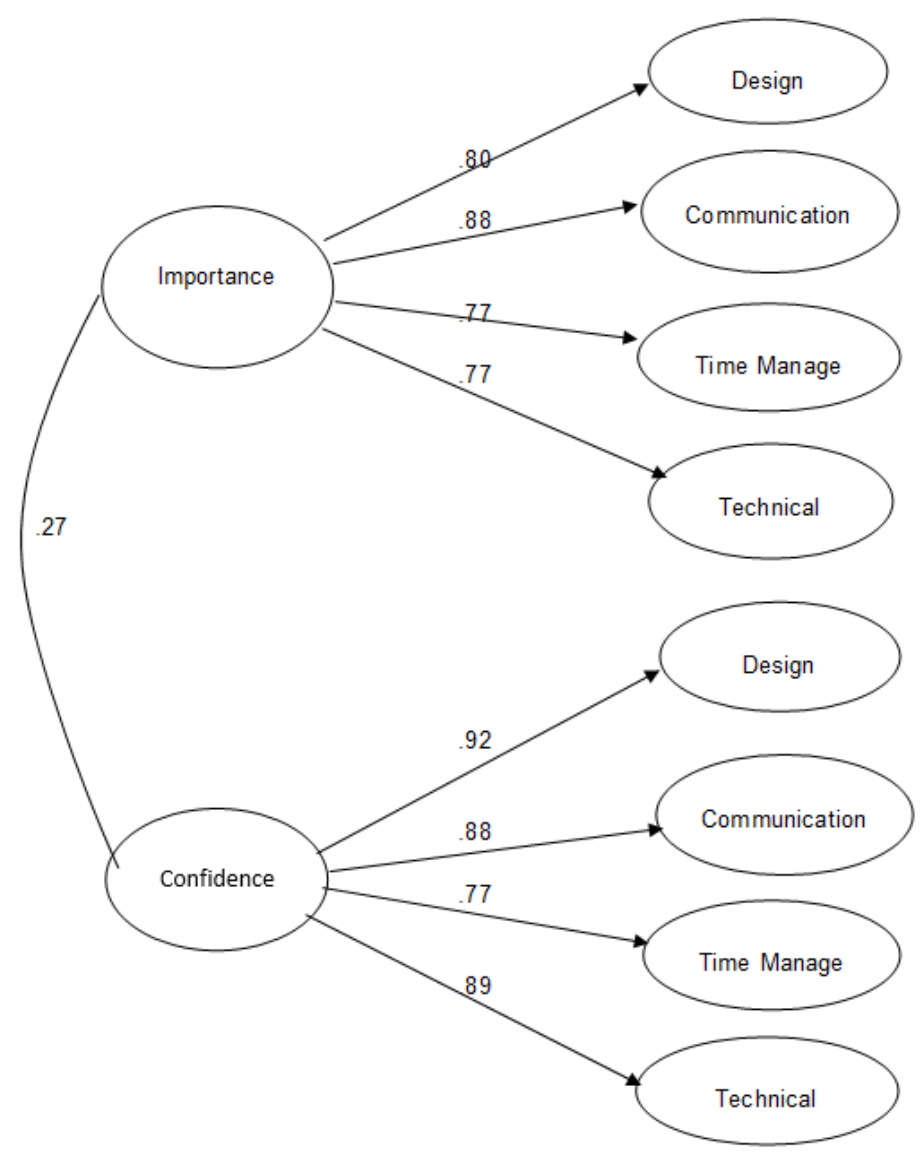

Figure 2. Two-level confirmatory factor analysis model.

Two pairs of items were allowed to covary because they shared a lot in common:

- Pair 1: Create online assignments (Course Design 8) and manage grades online (Course Design 9). Both items were about assignments, and managing grades is expected to be correlated to creating online assignments.

- Pair 2: Create instructional videos (Course Design 5) and create and edit videos (Technical Competence 5). Both items were about creating videos, so it not surprising that these two items should be highly correlated.

\section{Results}

\section{Faculty Perceptions on Their Attitude (Importance) and Ability (Confidence) to Teach Online}

Descriptive statistics (means and standard deviations) by item within each of the four subscales — course design, course communication, time management, and technical — are reported in Table 2. Most of the items on this survey were rated high for both attitude and ability.

Attitude (importance). In course design, designing learning activities $(M=4.63)$ and creating online course orientation $(M=4.50)$ were rated the highest. In course communication, responding to student questions promptly $(M=4.70)$ and providing feedback on assignments $(M$ 
$=4.65)$ were rated the highest. In time management, schedule time to design the course prior to delivery $(M=4.56)$ and spending weekly hours to grade $(M=4.44)$ were rated the highest. In technical, navigate within the course in the learning management system $(M=4.72)$ and complete basic computer operations $(M=4.58)$ were rated the highest.

Ability (confidence). In course design, organize instructional materials into modules or units $(M=4.68)$ and create online assignments $(M=4.62)$ were rated the highest. In course communication, use email to communicate with the learners $(M=4.82)$ and send announcements/email reminders $(M=4.77)$ were rated the highest. In time management, spending weekly hours to grade assignments $(M=4.47)$ and schedule weekly hours to facilitate the online course $(M=4.42)$ were rated the highest. In technical, complete basic computer operations $(M=$ $4.79)$ and navigate within the course in the learning management system $(M=4.62)$ were rated the highest.

Table 2

Descriptive Statistics on Survey Responses by Item

\begin{tabular}{|c|c|c|c|}
\hline & Faculty readiness competencies & $\begin{array}{c}\text { Attitude } \\
\text { (importance) } \\
M(S D)\end{array}$ & $\begin{array}{c}\text { Ability } \\
\text { (confidence) } \\
M(S D)\end{array}$ \\
\hline & Course Design & & \\
\hline 1 & $\begin{array}{l}\text { Create an online course orientation (e.g., introduction, } \\
\text { getting started) }\end{array}$ & $4.50(0.70)$ & $4.50(0.73)$ \\
\hline 2 & Write measurable learning objectives & $4.49(0.77)$ & $4.57(0.63)$ \\
\hline 3 & $\begin{array}{l}\text { Design learning activities that provide students } \\
\text { opportunities for interaction (e.g., discussion forums, wikis) }\end{array}$ & $4.63(0.64)$ & $4.44(0.76)$ \\
\hline 4 & Organize instructional materials into modules or units & $4.48(0.75)$ & $4.68(0.63)$ \\
\hline 5 & $\begin{array}{l}\text { Create instructional videos (e.g., lecture video, } \\
\text { demonstrations, video tutorials) }\end{array}$ & $3.80(1.00)$ & $3.93(0.97)$ \\
\hline 6 & $\begin{array}{l}\text { Use different teaching methods in the online environment } \\
\text { (e.g., brainstorming, collaborative activities, discussions, } \\
\text { presentations) }\end{array}$ & $4.35(0.78)$ & $4.33(0.84)$ \\
\hline 7 & Create online quizzes and tests & $3.73(1.09)$ & $4.41(0.82)$ \\
\hline 8 & Create online assignments & $4.48(0.73)$ & $4.62(0.68)$ \\
\hline \multirow[t]{3}{*}{9} & Manage grades online & $4.49(0.78)$ & $4.61(0.72)$ \\
\hline & Total & $4.33(0.50)$ & $4.45(0.60)$ \\
\hline & Course Communication & & \\
\hline 10 & Send announcements/email reminders to course participants & $4.64(0.59)$ & $4.77(0.56)$ \\
\hline 11 & Create and moderate discussion forums & $4.37(0.79)$ & $4.51(0.73)$ \\
\hline 12 & Use email to communicate with the learners & $4.35(0.84)$ & $4.82(0.41)$ \\
\hline 13 & $\begin{array}{l}\text { Respond to student questions promptly (e.g., } 24 \text { to } 48 \\
\text { hours) }\end{array}$ & $4.70(0.56)$ & $4.73(0.51)$ \\
\hline 14 & $\begin{array}{l}\text { Provide feedback on assignments (e.g., } 7 \text { days from } \\
\text { submission) }\end{array}$ & $4.65(0.63)$ & $4.63(0.58)$ \\
\hline 15 & $\begin{array}{l}\text { Use synchronous web-conferencing tools (e.g., Adobe } \\
\text { Connect, Webex, Blackboard Collaborate, Skype) }\end{array}$ & $3.53(1.06)$ & $4.00(1.03)$ \\
\hline 16 & $\begin{array}{l}\text { Communicate expectations about student behavior (e.g., } \\
\text { netiquette) }\end{array}$ & $4.38(0.74)$ & $4.48(0.68)$ \\
\hline 17 & $\begin{array}{l}\text { Communicate compliance regarding academic integrity } \\
\text { policies }\end{array}$ & $4.49(0.70)$ & $4.56(0.61)$ \\
\hline 18 & $\begin{array}{l}\text { Apply copyright law and fair use guidelines when using } \\
\text { copyrighted materials }\end{array}$ & $4.43(0.82)$ & $4.28(0.76)$ \\
\hline \multirow[t]{2}{*}{19} & Apply accessibility policies to accommodate student needs & $4.57(0.66)$ & $4.13(0.84)$ \\
\hline & Total & $4.41(0.47)$ & $4.50(0.46)$ \\
\hline
\end{tabular}




\begin{tabular}{|c|c|c|c|}
\hline & Time management & & \\
\hline 20 & $\begin{array}{l}\text { Schedule time to design the course prior to delivery (e.g., a } \\
\text { semester before delivery) }\end{array}$ & $4.56(0.70)$ & $4.33(0.75)$ \\
\hline 21 & Schedule weekly hours to facilitate the online course & $4.40(0.77)$ & $4.42(0.63)$ \\
\hline 22 & $\begin{array}{l}\text { Use features in learning management system in order to } \\
\text { manage time (e.g., online grading, rubrics, SpeedGrader, } \\
\text { calendar) }\end{array}$ & $4.29(0.85)$ & $4.29(0.83)$ \\
\hline 23 & $\begin{array}{l}\text { Use facilitation strategies to manage time spent on course } \\
\text { (e.g., discussion board moderators, collective feedback, } \\
\text { grading scales) }\end{array}$ & $4.05(0.84)$ & $4.07(0.93)$ \\
\hline 24 & Spend weekly hours to grade assignments & $4.44(0.73)$ & $4.47(0.57)$ \\
\hline \multirow[t]{3}{*}{25} & Allocate time to learn about new strategies or tools & $4.12(0.77)$ & $4.06(0.85)$ \\
\hline & Total & $4.31(0.56)$ & $4.27(0.57)$ \\
\hline & Technical competence & & \\
\hline 26 & $\begin{array}{l}\text { Complete basic computer operations (e.g., creating and } \\
\text { editing documents, managing files and folders) }\end{array}$ & $4.58(0.65)$ & $4.79(0.56)$ \\
\hline 27 & $\begin{array}{l}\text { Navigate within the course in the learning management } \\
\text { system (e.g., Moodle, Canvas, Blackboard, etc.) }\end{array}$ & $4.72(0.55)$ & $4.62(0.68)$ \\
\hline 28 & $\begin{array}{l}\text { Use course roster in the learning management system to set } \\
\text { up teams/groups }\end{array}$ & $3.85(0.89)$ & $4.25(0.90)$ \\
\hline 29 & $\begin{array}{l}\text { Use online collaborative tools (e.g., Google Drive, } \\
\text { Dropbox) }\end{array}$ & $3.85(0.94)$ & $4.30(0.88)$ \\
\hline 30 & Create and edit videos (e.g., iMovie, Movie Maker, Kaltura) & $3.55(1.08)$ & $3.79(1.10)$ \\
\hline 31 & $\begin{array}{l}\text { Share open educational resources (e.g., learning websites, } \\
\text { Web resources, games and simulations) }\end{array}$ & $3.95(0.91)$ & $4.23(0.88)$ \\
\hline \multirow[t]{3}{*}{32} & Access online help desk/resources for assistance & $4.27(0.79)$ & $4.48(0.69)$ \\
\hline & Total & $4.11(0.58)$ & $4.35(0.64)$ \\
\hline & Meal & $4.32(0.44)$ & $4.41(0.50)$ \\
\hline
\end{tabular}

Figure 3 shows the subscale means for attitude of importance and ability to confidently teach online. For course design, course communication, and technical, faculty rated their attitude higher than their perception of ability, whereas for time management their perception of ability was rated higher than their attitude.

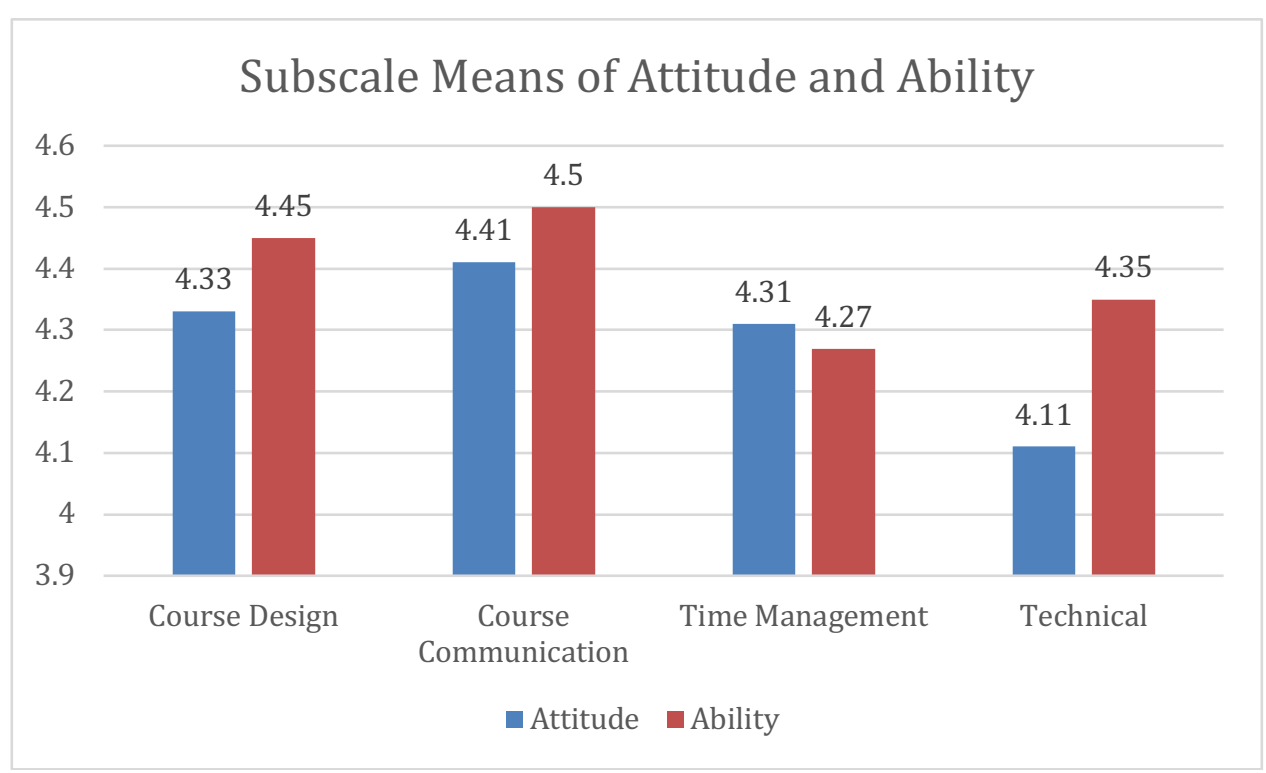

Figure 3. Subscale means of attitude and ability. 
Descriptive statistics on attitude and ability scores by demographic characteristics are reported in Table 3.

Table 3

Descriptive Statistics of Attitude (Importance) and Ability (Confidence) Scores by Demographic Characteristics

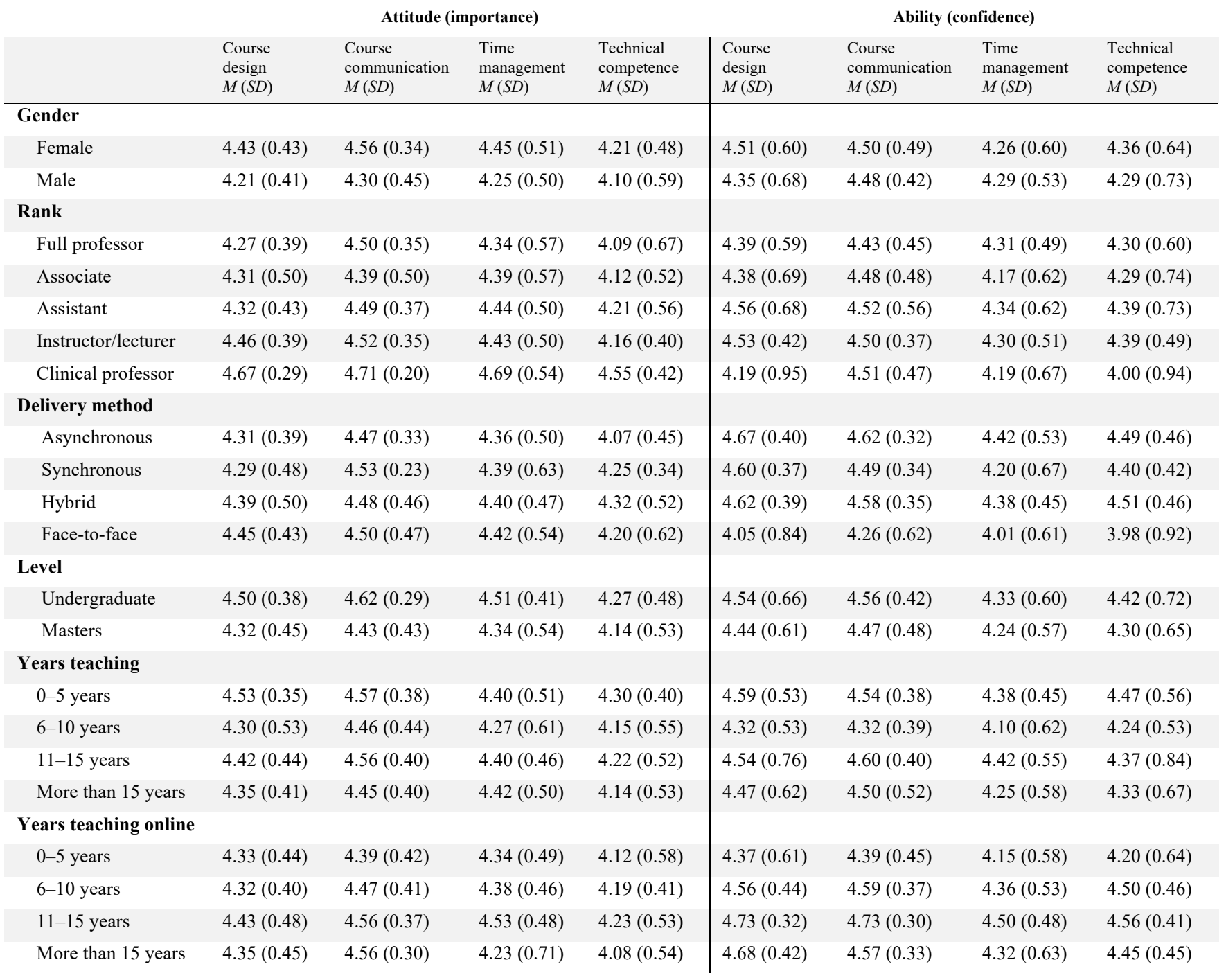

\section{Demographic Factors and Faculty Perceptions of Attitude of Importance and Ability to Confidently Teach Online}

Differences in faculty attitude and ability to teach online with respect to gender, rank, delivery method, level, years teaching, and years teaching online were examined using MANOVA. Statistically significant results of MANOVA (using Wilks' lambda) were followed by ANOVA. Results from ANOVA show significant differences in gender, years teaching online, and delivery method for faculty attitudes on importance of online teaching competencies. Results also showed significant differences in years teaching online and delivery method based on their perception of 
ability for online teaching. No significant differences were found between other demographic factors.

Gender. Female faculty attitudes were significantly higher than male faculty attitudes about the importance of course design, course communication, and time management. A significant difference was found between female and male faculty's attitudes about the importance of course design, $F(1,123)=9.11, p=.003$, partial $\eta^{2}=.07$ (moderate effect); course communication, $F(1,123)=17.09, p<.001$, partial $\eta^{2}=.12$ (moderate effect); and time management, $F(1,123)=6.59, p=.011$, partial $\eta^{2}=.05$ (small effect).

No significant difference was found between female and male faculty's attitude on the importance of technical competence and based on the perception of their ability.

Years teaching online. MANOVA showed no statistically significant associations between faculty's years of online teaching experience and a linear combination of all four subscales of attitude towards online teaching, Wilk's lambda $=0.03 ; F(12,594)=0.47, p=.93$. However, MANOVA results suggested statistically significant associations between faculty's years of online teaching experience and a linear combination of the four subscales of their perception of ability to teach online, Wilk's lambda $=0.90 ; F(12,518)=1.86, p=.04$. Specifically, the statistically significant differences were found in course design, $F(3,199)=6.01, p=.001$, partial $\eta^{2}=.08$ (moderate effect); course communication, $F(3,199)=5.76, p=.001$, partial $\eta^{2}=$ .08 (moderate effect); and technology skill, $F(3,199)=3.93, p=.01$, partial $\eta^{2}=.06$ (moderate effect).

Perception of ability in course design. Pairwise comparisons show that faculty with $0-5$ years of online teaching experience $(M=4.37 ; S D=0.61)$ have significantly lower perception of ability in course design than faculty with 6-10 years $(M=4.56 ; S D=0.44), 11-15$ years $(M=$ 4.73; $S D=0.32)$, and more than 15 years $(M=4.68 ; S D=0.42)$ online teaching experience.

Perception of ability in course communication. Pairwise comparisons show that faculty with $0-5$ years of online teaching experience $(M=4.39 ; S D=0.45)$ have significantly lower perception of ability in course communication than faculty with 6-10 years $(M=4.59 ; S D=0.37)$, $11-15$ years $(M=4.73 ; S D=0.30)$, and more than 15 years $(M=4.57 ; S D=0.33)$ online teaching experience.

Perception of ability in technical competence. Pairwise comparisons show that faculty with $0-5$ years of online teaching experience $(M=4.20 ; S D=0.64)$ have significantly lower perception of ability in technical competence than faculty with $6-10$ years $(M=4.50 ; S D=0.46)$ and $11-15$ years $(M=4.56 ; S D=0.41)$ online teaching experience.

Delivery method. Delivery method had a significant difference on faculty attitude on the importance of technical competence, $F(3,123)=3.79, p=.012$, partial $\eta^{2}=.09$ (moderate effect). Pairwise comparisons show that faculty who teach asynchronous courses $(M=4.07 ; S D=0.45)$ had a significantly lower perception of the importance of technical competence than faculty who teach hybrid courses $(M=4.32 ; S D=0.52)$.

Delivery method had a significant difference on faculty perception of ability in course design, $F(3,123)=3.90, p=.011$, partial $\eta^{2}=.09$ (moderate effect). Pairwise comparisons show that faculty who teach face-to-face courses $(M=4.05 ; S D=0.84)$ have a significantly lower perception of ability in course design than faculty who teach asynchronous courses $(M=4.67 ; S D$ $=0.40)$ and hybrid courses $(M=4.62 ; S D=0.39)$. 


\section{Discussion}

\section{Highest Rated Competencies}

An important finding from the study is that the competencies that faculty perceive as most important in all competency areas differ from the top competencies that faculty believe they can perform. These are discussed in depth in the next sections.

Designing online learning activities and course orientations. Designing learning activities and creating online course orientation were competencies that faculty rated as very important in online course design. Researchers have recommended that online teaching should focus on engaging learners through activities that facilitate the learning process (Ally, 2004). Course design should focus on learning activities that provide students opportunities for interaction (e.g., discussion forums, wikis), as interaction becomes more important in online learning due to the distance between students and time they spend online (Beldarrain, 2006). In addition to learning activities, starting a course with an effective orientation provides students with a satisfying course experience. Well-designed and effective orientations prepare students to do well in the course (Ko \& Rossen, 2001). Ali and Leeds (2009) discuss the value of orientation in online learning settings where the retention of students is lower than face-to-face courses.

Organizing online instructional materials and assessment. For their perception of their ability, faculty rated organizing instructional materials into modules and creating online assignments as the tasks that they can do well. Researchers have found that course design factors, such as organizing instructional materials into modules or units, are an essential aspect of success factors in distance education (Menchaca \& Bekele, 2008). In addition to course organizing, faculty perceived their ability to be high with regard to creating online assignments. Faculty need to know whether students have achieved course outcomes expected for the online course, and assignments, quizzes, and tests are a way to measure this. According to Pollanen (2007), keeping students motivated is important, especially in online classes, and well-designed assignments can help with that.

Promptly responding and giving feedback online. Responding to student questions and providing feedback were competencies that faculty rated as very important in online course communication. Providing timely responses is critical in online learning (Eskey \& Schulte, 2010; Sheridan \& Kelly, 2010), as it facilitates the learning process. Miller (2012) recommended faculty timely response to questions as one of the helpful facilitation strategies and recommended responding to questions within 24 to 48 hours as a best practice. Sheridan and Kelly (2010) discuss the value students attribute to timely feedback on their questions and problems. The faculty teaching presence and timely feedback enable the students to clarify misunderstandings about content and make progress towards learning goals. Thus, instructor feedback is a vital part of online learning and facilitates the learning process and enhances student learning (Cuthrell \& Lyon, 2007). Espasa and Meneses (2010) found a significant relationship between instructor feedback on students' assignments and their learning outcomes. Students who received feedback on their assignments had better performance than those who did not receive feedback.

Sending announcements and email communication. On their perception of ability, faculty rated using email to communicate with the learners and sending announcements/email reminders as the tasks they can do well. Communication in online classes takes place in different ways, and email and sending announcements through the learning management system are common ways that faculty communicate with their online students (Eskey \& Schulte, 2010). 
Regular announcements can be used to get students' attention, encourage them, remind them, and in general update students about the course. They also let students know that they are not alone in the learning process and that the faculty member is there to support them (Kelly, 2014). Ko and Rossen (2017) discuss that emails provide an opportunity to keep a record of the communication during the course. Cuthrell and Lyon (2007) also discuss email as a communication tool in online courses that enables faculty to reach out to all students.

Scheduling time for course design and grading. Scheduling time to design the course prior to delivery and spending weekly hours to grade assignments were competencies that faculty rated as very important in time management. Unlike face-to-face teaching, where faculty can design instructional material week by week, in an online course, the online faculty member is expected to have the course designed before the start of the semester. Hence, it is essential for faculty to realize the time that goes into designing the course and that they should have some time available before the course is offered. In addition, spending weekly hours to grade assignments was also rated as very important by faculty. An online faculty member spends more time grading, especially since all the discussions occur online. It is important that weekly hours are set aside for grading and that assignments be graded promptly so that students receive timely feedback.

For perception of ability, faculty rated spending weekly hours to grade assignments and scheduling weekly hours to facilitate the online course as tasks that they can do well. Faculty not only rated spending weekly hours to grade assignments as very important but also rated it as a task that they can do well. This stresses the importance of setting aside time to grade each week so that students receive feedback promptly. Evidently, our findings reveal that teaching online requires fixed allocation of scheduled time for course design and grading, as opposed to prior studies that suggest that online courses free up blocks of time and promote time shifting and flexibility for faculty (Wright, 2014). Cavanaugh (2005) reports that this happens as a result of high levels of interaction, involvement, and individualized instruction in online learning.

Managing the learning management system and documents. Online courses are delivered via a learning management system, and navigating the learning management system is an important competency. Our study showed that faculty rated navigating the learning management system and basic computer operations as two very important technical competencies. Faculty also rated these two competencies as ones in which they had high levels of ability. Faculty's knowledge about and use of technology tools (Gay, 2016) are very important in online teaching. Online faculty are expected to be proficient with basic computer operations, such as creating and editing documents and managing files and folders, since these make up a major portion of design and facilitation of an online course and are related to learning outcomes (Keramati, Afshari-Mofrad, \& Kamrani, 2011). Our findings agree with Wright's (2014) research that showed that faculty had a positive association with their technical skills and high levels of self-efficacy.

\section{Demographic Factors and Competencies}

Female faculty place higher importance on online competencies. With women having a greater preference for using technology in instruction than men do (Peluchette \& Rust, 2005), it is not surprising that there is a higher rate of female involvement in online teaching and course development (Seaman, 2009). Our sample similarly reflected that the majority of those teaching online are female $(72 \%)$. Results show that female faculty perceptions were significantly higher than male faculty perceptions about the importance of course design, course communication, and 
time management. The results of this study are similar to Briggs's (2005) survey, which found differences between genders in their perceptions of the importance of online teaching roles and competencies, and Chase (2002), who found differences in gender on instructional design practice, particularly on course design. Males and females tend to differ in communication styles, such that males see themselves as more precise, while females see themselves as more animated (Montgomery \& Norton, 1981). The differences in male and female communication styles influence how faculty communicate online. Time management is also a greater concern for female faculty than males, especially among those who have families.

Novice online faculty perceive that they are not ready for online teaching. Faculty who teach online can range from novice to expert in their ability. The experience gained from years of teaching online impacts online course design and facilitation. Our findings show that faculty with little to no online teaching experience have lower perceptions of their ability in online teaching than those with more than five years' experience. Most faculty have no formal education training, relying primarily on their experience as a student and face-to-face instructor. With the continuous change with online technologies, readiness to teach online may be in a state of flux (Varvel, 2007). It is not surprising that faculty new to online teaching have lower perceptions of their ability to teach online. The findings of this study are in agreement with Carril, Sanmamed, and Sellés (2013), who found that faculty with more teaching experience online have greater perceived levels of proficiency to perform pedagogical competencies. This indicates the need for faculty with little online teaching experience (i.e., less than five years) to experience high-quality online instruction, perhaps by participating in a course as a student. This will provide a sense of what more experienced faculty are doing in their online classes, which may in turn increase their perceptions of and confidence in their ability to teach online.

\section{Discussion}

Faculty attitudes on the importance of online teaching competency and their perception of their ability play a major role in how faculty approach online teaching goals, tasks, and challenges. Studies of online teaching competencies are important, as they provide information about how online faculty might be trained and supported by professional development initiatives in higher education institutions. When online teaching professional development programs are designed, it is important to cover aspects of competencies in this FRTO instrument, such as course design, course communication, technical, and time management, and specific attention should be given to competencies that faculty rated low in terms of importance and their perception of their own ability. The results of this study have implications for (1) faculty who are teaching online or getting prepared to teach online, (2) instructional designers who assist faculty in their preparation to teach online, and (3) administrators who can provide support for the faculty to prepare for online teaching. It is important for the faculty to be prepared in all four areas of online teaching: course design, course communication, time management, and technical.

\section{Limitations}

There were some methodological limitations in this study. First, the response rate was low, as we only received 205 complete responses from a 2,763 sampling frame. Although the response rate $(7 \%)$ was normal for online survey (Fan \& Yan, 2010; Manfreda, Bosnjak, Berzelak, Haas, \& Vehovar, 2006), the sample does not represent all of the target population who teach online. Cautions should be taken when generalizing the results from this study to all faculty. Second, we 
had a majority of the responses from faculty in education. It would have been helpful to have responses from faculty from various disciplines. Third, all data were self-reported due to the nature of the study. Some faculty may not be familiar with all the competencies for online teaching, and there might be a response bias. Finally, this list of competencies is not exhaustive. Readers should interpret the results with caution due to these limitations because results may have limited generalizability in different settings and contexts. Future researchers should consider Saleh and Bista's (2017) suggestions to increase the response rate for online surveys: interests of participants, survey structure, communication methods, and assurance of privacy and confidentiality. Future researchers could examine additional competencies and categories not included in this study. Future research could also examine specific online teaching settings, such as community colleges and $\mathrm{K}-12$. 


\section{References}

Ali, R., \& Leeds, E. (2009). The impact of classroom orientation in online student retention. Online Journal of Distance Learning Administration, 12(4), 1-9.

Ally, M. (2004). Foundations of educational theory for online learning. Theory and Practice of Online Learning, 2, 15-44.

Aydin, C. H. (2005). Turkish mentors' perception of roles, competencies and resources for online teaching. Turkish Online Journal of Distance Education, 6(3), 1-23.

Bawane, J., \& Spector, J. M. (2009). Prioritization of online instructor roles: Implications for competency-based teacher education programs. Distance Education, 30(3), 383-397.

Beldarrain, Y. (2006). Distance education trends: Integrating new technologies to foster student interaction and collaboration. Distance Education, 27(2), 139-153.

Berge, Z. L. (1995). Facilitating computer conferencing: Recommendations from the field. Educational Technology, 15(1), 22-30.

Briggs, S. (2005). Changing roles and competencies of academics. Active Learning in Higher Education, 6(3), 256-268.

Brooks, C. F. (2010). Toward "hybridised" faculty development for the twenty-first century: Blending online communities of practice and face-to-face meetings in instructional and professional support programmes. Innovations in Education and Teaching International, 47(3), 261-270.

Campbell, K., \& Varnhagen, S. (2002). When faculty use instructional technologies: Using Clark's delivery model to understand gender differences. Canadian Journal of Higher Education, 32(1), 31-56.

Carril, P. C. M., Sanmamed, M. G., \& Sellés, N. H. (2013). Pedagogical roles and competencies of university teachers practicing in the e-learning environment. The International Review of Research in Open and Distributed Learning, 14(3), 462-487.

Cavanaugh, J. (2005). Teaching online: A time comparison. Online Journal of Distance Learning Administration, 8(1), 1-11.

Chase, C. A. (2002). The impact of gender differences and levels of expertise in instructional design (Doctoral dissertation). Wayne State University.

Clay, M. (n.d.). Faculty attitudes toward distance education at the State University of West Georgia. Retrieved from http://www.westga.edu/ distance/attitudes.html

Cohen, J. (1988). Statistical power analysis for the behavioral sciences. Hillsdale, NJ: Lawrence Erlbaum Associates.

Coppola, N. W., Hiltz, S. R., \& Rotter, N. G. (2002). Becoming a virtual professor: Pedagogical roles and asynchronous learning networks. Journal of Management Information Systems, 18(4), 169-189. https://doi.org/10.1080/07421222.2002.11045703

Cuthrell, K., \& Lyon, A. (2007). Instructional strategies: What do online students prefer? Journal of Online Learning and Teaching, 3(4), 357-362. 
Darabi, A. A., Sikorski, E. G., \& Harvey, R. B. (2006). Validated competencies for distance teaching. Distance Education, 27(1), 105-122.

De Gagne, M. (2009). A model of knowledge-sharing motivation. Human Resource Management, 48(4), 571-589.

Denis, B., Watland, P., Pirotte, S., \& Verday, N. (2004). Roles and competencies of the e-tutor (pp. 150-157). Presented at the Networked Learning Conference, 2004, Lancaster.

Downing, J. J., \& Dyment, J. E. (2013). Teacher educators' readiness, preparation, and perceptions of preparing preservice teachers in a fully online environment: An exploratory study. The Teacher Educator, 48(2), 96-109.

Easton, S. S. (2003). Clarifying the instructor's role in online distance learning. Communication Education, 52(2), 87-105.

Eskey, M. T., \& Schulte, M. (2010). What online college students say about online instructors and what do online faculty members say about online instruction: A comparison of attitudes. Journal of Online Education, 1-20.

Espasa, A., \& Meneses, J. (2010). Analysing feedback processes in an online teaching and learning environment: An exploratory study. Higher Education, 59(3), 277-292.

Espiritu, J. L. (2016). Cultivating an e-learning culture. Presented at the National Conference on Technology in Education, SMX Mall of Asia, Manila, Philippines.

Fan, W., \& Yan, Z. (2010). Factors affecting response rates of the web survey: A systematic review. Computers in Human Behavior, 26, 132-139.

Fan, X., \& Sivo, S. A. (2005). Sensitivity of fit indexes to misspecified structural or measurement model components: Rationale of two-index strategy revisited. Structural Equation Modeling, 12(3), 343-367.

Fein, A. D., \& Logan, M. C. (2003). Preparing instructors for online instruction. New Directions for Adult and Continuing Education, 2003(100), 45-55. https://doi.org/10.1002/ace.118

Ferguson, G. A. (1954). On learning and human ability. Canadian Journal of Psychology 8(2), 95-112.

Gay, G. H. (2016). An assessment of online instructor e-learning readiness before, during, and after course delivery. Journal of Computing in Higher Education, 28(2), 199-220.

Goodyear, P., Salmon, G., Spector, J. M., Steeples, C., \& Tickner, S. (2001). Competences for online teaching: A special report. Educational Technology Research and Development, 49(1), 65-72.

Guasch, T., Alvarez, I., \& Espasa, A. (2010). University teacher competencies in a virtual teaching/learning environment: Analysis of a teacher training experience. Teaching and Teacher Education, 26(2), 199-206.

Gudea, S. F. W. (2005). Online teaching as experienced by teachers: A grounded theory perspective (Unpublished doctoral dissertation). The Claremont Graduate University.

Gunawardena, C. N. (1992). Changing faculty roles for audiographics and online teaching. American Journal of Distance Education, 6(3), 58-71. 
Hu, L., \& Bentler, P. M. (1999). Cutoff criteria for fit indexes in covariance structure analysis: Conventional criteria versus new alternatives. Structural Equation Modeling: A Multidisciplinary Journal, 6(1), 1-55.

Johnson, B., \& Christensen, L. (2004). Educational research: Quantitative, qualitative, and mixed approaches (2nd ed.). Boston, MA: Allyn and Bacon.

Kelly, R. (2014). Five things online students want from faculty. FACULTY FOCUS: Higher Ed Teaching Strategies. Retrieved from https://www.facultyfocus.com/articles/onlineeducation/online-students-want-from-faculty/

Keramati, A., Afshari-Mofrad, M., \& Kamrani, A. (2011). The role of readiness factors in Elearning outcomes: An empirical study. Computers \& Education, 57(3), 1919-1929.

Kim, H. S., Kim, M. S., \& Park, M. H. (2009). Analysis of nursing students' knowledge, attitude and ability to perform cardiopulmonary resuscitation. Journal of Korean Academy of Fundamentals of Nursing, 16(4), 430-437.

Ko, S., \& Rossen, S. (2017). Teaching online: A practical guide. Oxon: Routledge.

Krosnick, J. A., \& Petty, R. E. (1995). Attitude strength: An overview. Attitude strength: Antecedents and Consequences, 1, 1-24.

Lee, M. H., \& Tsai, C.-C. (2010). Exploring teachers' perceived self efficacy and technological pedagogical content knowledge with respect to educational use of the World Wide Web. Instructional Science, 38(1), 1-21.

Lichoro, D. M. (2015). Faculty readiness for transition to teaching online courses in the Iowa Community College Online Consortium (Unpublished doctoral dissertation). Iowa State University, Iowa.

Logan, S., \& Johnston, R. (2009). Gender differences in reading ability and attitudes: Examining where these differences lie. Journal of Research in Reading, 32(2), 199-214.

MacCallum, R. C., Roznowski, M., \& Necowitz, L. B. (1992). Model modifications in covariance structure analysis: The problem of capitalization on chance. Psychological Bulletin, 111(3), 490-504.

Manfreda, K. L., Bosnjak, M., Berzelak, J., Haas, I., \& Vehovar, V. (2008). Web surveys versus other survey modes. International Journal of Market Research, 50, 79-104.

Marsh, H. W., Hau, K.-T., \& Wen, Z. (2004). In search of golden rules: Comment on hypothesistesting approaches to setting cutoff values for fit indexes and dangers in overgeneralizing Hu and Bentler's (1999) findings. Structural Equation Modeling, 11(3), 320-341.

Menchaca, M. P., \& Bekele, T. A. (2008). Learner and instructor identified success factors in distance education. Distance Education, 29(3), 231-252.

Messick, S. (1995). Validity of psychological assessment: Validation of inferences from persons' responses and performances as scientific inquiry into score meaning. American Psychologist, 50(9), 741-749.

Miller, J. M. (2012). Finding what works online: Online course features that encourage engagement, completion, and success (Doctoral dissertation, California State University, Northridge). 
Montgomery, B. M., \& Norton, R. W. (1981). Sex differences and similarities in communicator style. Communications Monographs, 48(2), 121-132.

Moore, M. G. (1993). Theory of transactional distance. Theoretical Principles of Distance Education, 1, 22-38.

Napier, N. P., Dekhane, S., \& Smith, S. (2011). Transitioning to blended learning: Understanding student and faculty perceptions. Journal of Asynchronous Learning Networks, 15(1), 20-32.

Northcote, M., Gosselin, K., \& Reynaud, D. (2015). Navigating learning journeys of online teachers: Threshold concepts and self-efficacy. Issues in Educational Research, 25(3), 319-344.

Pagliari, L., Batts, D., \& McFadden, C. (2009). Desired versus actual training for online instructors in community colleges. Retrieved from http://thescholarship.ecu.edu/handle/10342/2176

Palloff, R. M., \& Pratt, K. (1999). Building learning communities in cyberspace (Vol. 12). San Francisco: Jossey-Bass.

Peluchette, J. V., \& Rust, K. A. (2005). Technology use in the classroom: Preferences of management faculty members. Journal of Education for Business, 80(4), 200-205.

Pennsylvania State University (2017). Faculty self-assessment: Preparing for online teaching. Retrieved from https://behrend-elearn.psu.edu/weblearning/FacultySelfAssessment/

Pollanen, M. (2007). Improving learner motivation with online assignments. Journal of Online Learning and Teaching, 3(2), 203-213.

Redmond, P. (2011). From face-to-face teaching to online teaching: Pedagogical transitions. In G. Williams, P. Statham, N. Brown, \& B. Cleland (Eds.), Proceedings ASCILITE 2011: 28th Annual Conference of the Australasian Society for Computers in Learning in Tertiary Education: Changing Demands, Changing Directions (pp. 1050-1060). Gold Coast, Australia: Australasian Society for Computers in Learning in Tertiary Education (ASCILITE).

Richey, R. C., Fields, D. C., \& Foxon, M. (2001). Instructional design competencies: The standards (3rd ed.). Syracuse, NY: ERIC Clearinghouse on Information \& Technology.

Rollnick, S., Mason, P., \& Butler, C. C. (2010). Health behavior change e-book. Elsevier Health Sciences.

Ryan, M., Carlton, K. H., \& Ali, N. S. (2004). Reflections on the role of faculty in distance learning and changing pedagogies. Nursing Education Perspectives, 25(2), 73-80.

Saleh, A., \& Bista, K. (2017). Examining factors impacting online survey response rates in educational research: Perceptions of graduate students. Journal of MultiDisciplinary Evaluation, 13, 63-74.

Seaman, J. (2009). Online learning as a strategic asset. Volume II: The paradox of faculty voices - views and experiences with online learning. Results of a national faculty survey, part of the online education benchmarking study conducted by the APLU-Sloan National Commission on Online Learning. Association of Public and Land-Grant Universities. 
Shea, P. (2007). Bridges and barriers to teaching online college courses: A study of experienced faculty in thirty-six colleges. Journal of Asynchronous Learning Networks, 11(2), 73128.

Sheridan, K., \& Kelly, M. A. (2010). The indicators of instructor presence that are important to students in online courses. Journal of Online Learning and Teaching, 6(4), 767.

Sorcinelli, M. D., \& Austin, A. E. (2006). Developing faculty for new roles and changing expectations. Effective Practices for Academic Leaders, 1(11), 1-16.

Spotts, T., Bowman, M., \& Mertz, C. (1997). Gender and use of instructional technologies: A study of university faculty. Higher Education, 34(4), 421-436.

Turner, C. W. (2005). Voices of faculty and students: Exploring distance education at a state university (Unpublished doctoral dissertation). New Mexico State University.

University of Toledo (2017). Faculty online teaching readiness. Retrieved from https://www.utdl.edu/lv/assessments/faculty_readiness.html

Varvel, V. E. (2007). Master online teacher competencies. Online Journal of Distance Learning Administration, 10(1), 1-41.

Visser, J. A. (2000). Faculty work in developing and teaching web-based distance courses: A case study of time and effort. American Journal of Distance Education, 14(3), 21-32. https://doi.org/10.1080/08923640009527062

Volery, T. (2000). Critical success factors in online education [Electronic version]. The International Journal of Educational Management, 14(5), 216-223.

Wallace, R. M. (2004). A framework for understanding teaching with the Internet. American Educational Research Journal, 41(2), 447-488. https://doi.org/10.3102/00028312041002447

Williams, P. E. (2003). Roles and competencies for distance education programs in higher education institutions. The American Journal of Distance Education, 17(1), 45-57.

Wray, M., Lowenthal, P. R., Bates, B., \& Stevens, E. (2008). Investigating perceptions of teaching online \& f2f. Academic Exchange Quarterly, 12(4), 243-248.

Wright, J. M. (2014). Planning to meet the expanding volume of online learners: An examination of faculty motivation to teach online. Educational Planning, 21(4), 35-49.

Young, J. R. (1997). Rethinking the role of the professor in an age of high-tech tools. Chronicle of Higher Education, 44(6), 26-28. 